\title{
Bacterial Colonization of Leaves: A Spectrum of Strategies
}

\author{
Gwyn A. Beattie and Steven E. Lindow
}

First author: Department of Microbiology, Iowa State University, Ames 50011-3211; and second author: Department of Plant and Microbial

Biology, University of California, Berkeley 94720-3102.

Accepted for publication 21 January 1999.

\begin{abstract}
Beattie, G. A., and Lindow, S. E. 1999. Bacterial colonization of leaves: A spectrum of strategies. Phytopathology 89:353-359.

Bacteria associated with plant leaves, or phyllobacteria, probably employ a range of colonization strategies. Steps in these colonization strategies include modification of the leaf habitat, aggregation, ingression, and egression. Considerable evidence indicates that bacteria can modify their environment to enhance their colonization of plants, such as by increasing local nutrient concentrations or by producing a layer of extracellular polysaccharides. This local habitat modification may occur on the surface of leaves, as well as in the leaf interior, and may be enhanced by the formation of bacterial aggregates. The conspicuous presence of bacterial aggregates on leaves and the finding that the behavior of bacteria on plants varies in a density-dependent manner indicate the potential importance of cooperative interactions among phyllobacteria. Such cooperative interactions may

identified, there is strong circumstantial evidence that a sizable proportion of cells, particularly of phytopathogenic strains, are localized within "protected sites" on plants. The likelihood that these protected sites are located in the interior of leaves indicates that phytopathogenic bacteria have access to more resources and greater protection from stresses associated with the leaf surface than bacteria that are restricted to the leaf surface. The internal and external leaf-associated populations probably form a continuum due to the processes of ingression and egression. For a specific pathogen, however, the extent of egression that occurs prior to disease induction is likely to influence the success of disease predictions based on external population size, i.e., the number of bacteria in leaf washings. In this review, we illustrate the complexity of the ecology of leaf-associated bacteria and propose a model of leaf colonization that emphasizes the common elements in bacterial colonization strategies, as well as allows for distinct behavior of different phyllobacterial species.
\end{abstract} occur among both homogeneous and heterogeneous populations, thus influencing the development of microbial communities. While the sites commonly colonized by most phyllobacteria have not been unambiguously

Bacteria are common residents of leaves. Some phyllosphere communities have been found to consist of more than 78 bacterial species representing 37 bacterial genera $(57,90)$. This diverse collection of bacteria found on leaves often includes a few that can visibly influence the health of host plants under suitable conditions, such as by inciting disease or ice formation or by producing plant hormones that alter plant growth. Often, it also includes many bacterial species that can establish large populations without any apparent effect on the plant. In our current plant-centered terminology, we refer to those that can incite disease as pathogens and to all others as nonpathogens or saprophytes. From the perspective of the bacteria, however, this simplistic separation may both obscure the complex range of interactions that bacteria have with their host plant and limit our understanding of bacterial ecology. For example, can bacteria actively acquire nutrients from a plant without inducing visible disease symptoms? Can bacteria colonize the internal regions of leaves without inducing visible disease symptoms? Does such internal colonization offer enhanced opportunities for bacterial growth and survival? Are bacterial colonization strategies related to pathogenesis?

Epiphytic bacteria have been defined as bacteria that are capable of living (i.e., multiplying) on plant surfaces $(40,52)$. The term "epiphytic" thus appropriately evokes images of bacteria that are located, at least primarily, on the surfaces of leaves. Although some leaf residents may establish only surface populations, others such as foliar pathogens can establish internal populations. In this review, we will use the term "epiphytic bacteria" to refer to those bacteria located on leaf surfaces. As a parallel to the term "rhizo-

Corresponding author: G. A. Beattie: E-mail address: gbeattie@iastate.edu

Publication no. P-1999-0225-01V

(C) 1999 The American Phytopathological Society
Additional keywords: epiphyte, Erwinia herbicola, foliar pathogen, Pseudomonas syringae, saprophyte, Xanthomonas campestris.

bacteria" used for root-associated bacteria, we will use the term "phyllobacteria" to refer to all of the bacteria associated with a leaf, regardless of their location. This designation is more inclusive of the potentially complex life cycles of the many diverse bacteria associated with plant leaves.

In a previous review (10), we explored two strategies that bacteria may use to survive the large and rapid fluctuations in environmental conditions that occur on a leaf surface. A strategy of tolerance requires the ability to tolerate direct exposure to UV radiation, low water availability, and other environmental stresses on leaf surfaces. In contrast, a strategy of avoidance requires the ability to seek and exploit sites that are protected from these stresses, including sites in the internal leaf regions. Among bacteria associated with leaves, there is probably a spectrum from those that employ solely a tolerance strategy and establish populations only on leaf surfaces, to those that employ both strategies to various extents, to those that employ an avoidance strategy and establish populations only in the internal leaf regions. In this review, we further illustrate the complexity in the ecology of phyllobacteria by extending our focus beyond simply survival to a broader perspective of leaf colonization.

\section{LOCATION OF BACTERIA ON LEAF SURFACES}

Leaf imprint studies demonstrate that bacteria do not occur in a uniform pattern across leaf surfaces, but are localized in particular sites $(55,56,94)$. The nature of these sites has been examined by various microscopic techniques. In studies using scanning electron microscopy (SEM), the most common sites of bacterial colonization were at the base of the trichomes $(6,53,62,65,69,92)$, at stomata $(62,63,65,69,70,76,92)$, and at the epidermal cell wall junctions $(14,22,53)$, especially in the grooves along the veins $(55,62,65)$. Bacteria were also found in depressions in the cuticle (62), beneath 
the cuticle (18), near hydathodes (68), and in structures specific to particular plants such as the stomatal pits in oleander and the shields of pectate hairs in olive (86). In general, larger numbers of bacteria were found on lower than on upper leaf surfaces $(17,55,70,86$, $94)$, possibly due to the lower surface having a higher density of stomata or trichomes $(21,62,70,86)$ or a thinner cuticular layer.

Quantitative differences in bacterial abundance in closely proximal portions of a leaf can be great. Kinkel et al. (50) noted that total bacterial populations varied by over 100 -fold among small segments $\left(9 \mathrm{~mm}^{2}\right)$ of potato leaves and that the variation of bacteria among leaf segments was best described by a log-normal distribution (50). J.-M. Monier and S. E. Lindow (unpublished data), using microscopic examination of leaves, noted that bacterial abundance varied greatly among randomly chosen leaf segments of about $0.1 \mathrm{~mm}^{2}$ and that a log-normal distribution also best described the variation in bacterial population sizes at this small scale. Morris et al. (71) recently described the occurrence of large aggregates of bacteria on a variety of plants grown in the field; such aggregates were often highly localized, with few other bacteria in their immediate vicinity. The aggregated nature of bacterial colonists of plant surfaces is a conspicuous feature that presumably has important implications for the interactions of these microbes with themselves on leaves, as well as with the plant itself. For example, the processes leading to the development of aggregates may be key processes in leaf colonization. Do aggregates result from bacterial localization into discrete sites that favor growth and survival? Do aggregates result from the ability of bacteria to create such sites by modifying their local environment? These questions will be explored in the remainder of this review.

\section{MODIFICATION OF THE LEAF SURFACE ENVIRONMENT}

\section{Enhancement of host nutrient leakage on leaf surfaces}

Considerable evidence indicates that bacteria can modify their environment to enhance their colonization of plants, such as by increasing nutrient concentrations on plant surfaces. For example, the study of indole-3-acetic acid (IAA)-producing bacteria, which are common on plants $(30,32,61)$, reveals that bacterial IAA production may play a role in enhancing nutrient leakage $(15,64)$. Epiphytic populations of a parental IAA-producing strain of Pantoea agglomerans (formerly Erwinia herbicola) increased to approximately twice that of an isogenic IAA-deficient mutant of this species after coinoculation in a proportion of $1: 1$ onto bean plants in the greenhouse and onto pear flowers in field studies (15). In all experiments, the ratio of the population sizes of the parental and IAA-deficient mutant strains increased during periods of growth on plants, but not when population sizes remained static with time (15). IAA production was also associated with increased survival of Pantoea agglomerans on leaves under stressful conditions (64). IAA-deficient mutants of Pseudomonas syringae also exhibited slightly different growth dynamics on bean plants in a greenhouse study (66). The enhanced growth rate of IAA-producing strains of Pantoea agglomerans was attributed to a slight increase in the nutrients available to the IAA-producing strain on the leaf, since there is evidence that low nutrient levels commonly limit bacterial growth and population sizes on plants $(15,99,100)$. Since exogenously applied auxins have been demonstrated to stimulate the release of monosaccharides and oligosaccharides from the plant cell wall (31, 33 ), it seems reasonable to assume that bacterial IAA production benefits the producing cells by similarly increasing nutrient availability in the vicinity of bacteria.

\section{Extracellular polysaccharide (EPS) production on leaf surfaces}

Bacteria may also modify their environment by producing a layer of EPS on leaf surfaces. Scanning electron micrographs reveal strands of amorphous material that emanate from and between bac- terial cells on leaves $(22,63,65,70,76,86,92)$. These strands probably represent the dehydrated remnants of a more complete matrix that originally surrounded the cell. The presence of EPS is particularly evident in recent images of large aggregates of bacteria on plant surfaces (71). In these images, the bacteria are closely packed but clearly embedded in an amorphous material that is presumably EPS of bacterial origin (71). EPS may anchor cells to the leaf surface and prevent cells from desiccation $(54,96)$, as well as modify the environment around the cell to one more favorable for growth and survival. This matrix may be analogous to that of biofilms, in which many aquatic microorganisms are found. Biofilms can concentrate nutrients from dilute sources, provide protection from predators, and shield cells from lytic enzymes, antibiotics, and other inhibitory compounds (19). Thus, bacterial production of such a matrix on leaves could be highly advantageous for growth and survival. It seems clear that epiphytic bacteria have modified their environment to one that does not resemble the exposed cuticular surface of plants. We need further information as to how different the chemical and physical environment within such bacterial assemblages on leaves are from what would be expected of cells isolated on the surface of plants.

\section{Density-dependent behavior}

There is strong evidence that the behavior of bacteria on plants varies in a density-dependent manner. For example, the survival of a strain of $P$. syringae exposed to desiccation stress under controlled conditions after application to plants was strongly dependent on the population density of the applied bacterium. Cells in inocula with high cell concentrations exhibited up to 100 -fold better survival on leaves than cells in inocula of low cell concentration (98). Likewise, the survival of cells of two $P$. syringae strains varied greatly after application to different plant species in a "common garden" experiment in the field, and a strong correlation was seen between the population size of indigenous bacteria on a plant species and the population size of $P$. syringae that survived inoculation onto plants (51). A positive correlation was also found between the population sizes of a particular strain of $P$. syringae that had been inoculated onto plants in a field study and the subsequent total $P$. syringae populations (i.e., all $P$. syringae strains) on individual leaflets throughout the growing season (42). Such results suggest that leaves colonized by bacteria provide a habitat that is different from that of uncolonized leaves and that leaf surface modifications made by bacterial epiphytes to facilitate their colonization of the leaf also benefit immigrants to the same leaf. The implication of these observations is that bacterial interactions within aggregates may induce qualitatively different traits than those expressed in individual cells. Such traits may be favorable for growth and survival and would cause a nonuniform distribution of bacteria to develop with time on leaves.

\section{LOCALIZATION BEYOND THE LEAF SURFACE}

While the location of leaf-associated bacteria has not been unambiguously determined in most cases, there is strong circumstantial evidence that a sizable proportion of cells of phyllobacteria, particularly phytopathogenic strains, are localized within "protected sites" on plants. Often, only a fraction of the bacterial populations that develop on leaves can be washed off, indicating that many cells may be in sites that prevent removal or may tightly adhere to leaf surfaces. For example, several days after inoculation of rifampinresistant Xanthomonas campestris pv. vesicatoria or $P$. syringae pv. phaseolicola strains onto bean leaves under dry field conditions, only 1 to $35 \%$ of the total population of rifampin-resistant bacteria isolated from treated leaves was recovered in the leaf washings $(17,84,94)$. Similarly, several days after inoculation of various rifampin-resistant $P$. syringae pathovars onto plants under controlled conditions, only 20 to $24 \%$ of the total population of rifampin-resistant bacteria isolated from treated leaves were recovered in leaf 
washings (72). In most studies, surface sterilants did not kill large numbers of leaf-associated bacteria, suggesting that the bacteria reside in protected sites. For example, after various phytopathogens were sprayed onto plants and allowed to colonize, between $10^{2}$ and $10^{7}$ cells per g survived exposure of the leaves to sodium hypochlorite $(6,7,37,79,80)$. Similar results were observed with topical applications of ethanol $(83,92)$ and hydrogen peroxide $(8,97)$ and with exposure of leaf surfaces to UV radiation $(5,36,74,89,97)$.

Identifying the exact location of phyllobacterial populations can be difficult and is strongly dependent on the methodology. It is clear that leaf-associated bacterial populations include those cells that are located on the surface of leaves, i.e., external populations, and those located in the leaf intercellular spaces, i.e. internal populations. Microscopy studies including both scanning and transmission electron microscopy have documented the presence of both externally and internally located bacteria $(22,25,81)$. In population studies, however, external populations are generally identified as those that are released by washing or sonication or those that are sensitive to surface sterilants. Unfortunately, we do not know the extent to which internal populations are released or are killed during these procedures. Quantifying internal populations is similarly complicated, since they are generally defined as those that are not external. Despite these limitations, it is noteworthy that, in one study, phytopathogenic bacteria exhibited a much higher proportion of cells that escaped surface sterilization with hydrogen peroxide or UV irradiation than did nonpathogenic strains on compatible host plants (97). The population size of bacterial strains that escaped surface sterilization was strongly correlated with the population size that each strain was able to achieve after infiltration into a plant; phytopathogenic bacteria developed high population sizes within plants, while nonpathogenic bacteria exhibited little or no growth (97). These results suggest that phytopathogenic bacteria have a unique ability to exploit the interior of plants prior to infection, providing them not only additional resources, but perhaps also enabling them to avoid stresses associated with the leaf surface (10).

\section{MODIFICATION OF THE ENVIRONMENT IN THE LEAF INTERCELLULAR SPACES}

\section{Enhancement of host nutrient leakage from plant host cells}

Habitat modification may occur inside plants, as well as on the exterior of plants. Specifically, phytopathogenic bacteria appear to modify the environment in the leaf intercellular spaces to make it more favorable for bacterial multiplication. Pathogens have been commonly observed to increase host cell membrane permeability $(1,16,95)$. This leakage may increase the amount of water and nutrients available to bacteria in the intercellular spaces $(3,4)$. Plant growth hormones such as auxins, which have been demonstrated to induce plant cell wall loosening and membrane leakiness (58), can be produced by many plant-associated bacteria including $P$. syringae pv. savastanoi $(30,32,61)$. The phytotoxin syringomycin may also induce leakiness in plant cell membranes (35). Studies with mutants deficient in the production of two other phytotoxins, coronatine and tabtoxin, showed that these phytotoxins were not important for establishing large endophytic populations, but were important for maintaining them $(13,93)$. While studies with syringomycin-deficient mutants of $P$. syringae pv. syringae showed that syringomycin was not required for establishing large endophytic populations $(73,101)$, the role of syringomycin in population maintenance was not evaluated.

\section{EPS production in plant intercellular spaces}

Another adaptation that may alter the intercellular environment is bacterial production of EPS. In the mesophyll spaces, as well as in surface sites, water is probably the most important factor influencing microbial growth. The continuous presence of water on the leaf surface often results in larger epiphytic microbial populations
(36); similarly, the continued water-soaking of leaves after infiltration with bacteria resulted in larger endophytic populations than in leaves that were allowed to dry (104). The retention of water in the highly hygroscopic polysaccharide matrix that typically envelopes bacteria in the intercellular spaces should increase the water available to the bacteria. For example, purified EPS from several phytopathogens induced persistent water-soaking after introduction by infiltration into leaves (28). Similar to that observed on the leaf surface, this EPS matrix may serve many other functions (24). Thus, even in asymptomatic plants, bacteria can apparently modify the environment both inside and outside the plant to improve the habitat (without visibly causing disease). This ability to colonize healthy plants without eliciting either a disease or a defensive response suggests that pathogens must have the ability to suppress, evade, or resist plant defenses (10).

\section{Cooperation among bacteria}

These forms of habitat modification may be augmented by cooperative interactions among bacteria, and these interactions may occur among both homogeneous and heterogeneous populations. The occurrence of aggregated populations of phyllobacteria, most commonly present as cells encased in an EPS matrix, would seem to maximize the opportunities for interactions to occur among the members of the group. There have been many recent descriptions of density-dependent interactions that occur among bacterial cells $(11,34,75,88)$. Such density-dependent interactions are often mediated by a strategy in which bacteria sense the presence of neighboring cells by detecting an increase in the concentration of constitutively produced extracellular molecules, usually one or more $\mathrm{N}$-acyl homoserine lactones (HSL) $(34,88)$. Apparently, this "quorum-sensing" strategy is dependent on the localized concentration of cells in a habitat in which the HSL signal molecules are contained, rather than a numerical threshold of bacterial cells per se. In an environment where localized bacterial abundance exceeds a threshold level, such HSL signal molecules can be involved in enhancing the transcription of a variety of genes via an autoregulatory signal transduction mechanism $(11,34,75,88)$. Genes involved in EPS and antibiotic production, as well as virulence traits, are known to be induced by this mechanism $(11,34,75,88)$. Since many plant-associated bacteria, including most phyllobacteria, apparently produce HSLs $(11,34,75,88)$, such density-dependent expression of these traits may be common.

\section{LOCATION OF BACTERIAL POPULATIONS IN RELATION TO DISEASE INDUCTION}

External and internal leaf-associated populations probably form a continuum due to the processes of ingress and egress. Evidence for the occurrence of ingress is strong. Numerous studies suggest that surface application of pathogens results in internal colonization $(17,20,38,72,92)$. Furthermore, a recent study demonstrates that at least one foliar pathogen, $X$. campestris pv. campestris, employs an active rather than a passive process to enter into leaves (44). There is mounting evidence for egress onto the leaf surface. SEM images suggest that many $P$. syringae and $X$. campestris pathovars are extruded onto leaf surfaces, usually through stomata $(6,7,10$, $70,77)$, but in some cases through wounds (23) and lesions (62). Water-soaking may contribute to egression, since $X$. campestris pv. malvacearum mutants that were reduced in their ability to induce water-soaking, but not in the ability to multiply in internal leaf tissues, were also reduced 240- to 1,600-fold in their leaf surface populations following infiltration into leaves (103). The formation of cankers and rupturing of epidermal layers by organisms such as $X$. citri may also enhance egression (87). The recent finding of Yang et al. $(102,103)$ that up to $14 \%$ of a X. campestris pv. malvacearum population was present on the leaf surface after infiltration of leaves indicates that egression may be of quantitative importance to external populations. Furthermore, W. P. Moss and M. Wilson (personal communication) found that epiphytic populations of $X$. 
campestris pv. vesicatoria decrease greatly after external inoculation and that this decrease is followed by an increase in internal population size and a subsequent increase in epiphytic population size. This observation indicates that at least with one organism, $X$. campestris pv. vesicatoria, egress may be the primary means of establishing external populations.

Although the external and internal populations likely form a continuum, it is generally believed that the internal populations are directly responsible for disease induction. As early as 1949, it was "generally accepted that disease symptoms due to bacterial leaf infection are correlated rather closely with bacterial multiplication in the intercellular spaces" (2). Dose-response curves have been used to demonstrate the requirement for large internal populations in disease induction (29). Furthermore, numerous bacterial genes have been identified that upon inactivation result in reduced internal growth and an apparent inability or reduced ability to induce disease. The functions of these genes include the induction of the hypersensitive response ( $h r p$ genes) $(43,47)$, bacterial swarming (48), synthesis of an outer-membrane polysaccharide (ops $X$ ) (49), and epiphytic fitness (estA and estB) (8; G. A. Beattie and S. E. Lindow, unpublished data). Although internal populations may be most important to disease induction, the relationship between external populations and disease has been more closely examined. Large external populations have been associated with the onset and severity of foliar diseases caused by several pathogens including $P$. syringae pvs. coronafaciens (39), glycinea (67), papulans (12), syringae $(41,59,78)$, and tomato $(82) ; X$. campestris pvs. phaseoli (94) and undulosa (26); X. translucens pv. translucens (85); and $E$. amylovora (91). A clear quantitative relationship between external population size and the probability of disease occurrence has been established for bacterial brown spot of beans by $P$. syringae pv. syringae $(59,78)$, halo blight of oats by $P$. syringae pv. coronafaciens (39), and frost injury by ice-nucleating bacteria (60), and has been suggested by preemptive exclusion studies of bacterial speck of tomato by $P$. syringae pv. tomato $(45,46)$.

This finding that large external population sizes and disease occurrence are correlated for some foliar diseases, combined with the likelihood that large internal populations are required for disease induction, suggests that external and internal populations are related. The few studies that have measured the size of both external and internal populations on the same leaf samples demonstrated that external and internal populations of three foliar pathogens, $P$. syringae pv. phaseolicola (84), X. campestris pv. citrumelo (27), and $X$. campestris pv. phaseoli (17), exhibited similar dynamics over a 20- to 30-day period. Additionally, several mutants have been examined for their ability to establish both internal and external populations including $P$. syringae pv. syringae epiphytic fitness mutants $(8,9), X$. campestris pv. vesicatoria, and $P$. syringae pv. tomato hrp mutants (W. P. Moss and M. Wilson, personal communication). All of these exhibited reductions in both internal and external populations. These studies provide evidence that factors that influence the size of one population can influence the size of the other. It is also possible that genes that are induced at a high cell density or upon a transition into stationary phase in externally

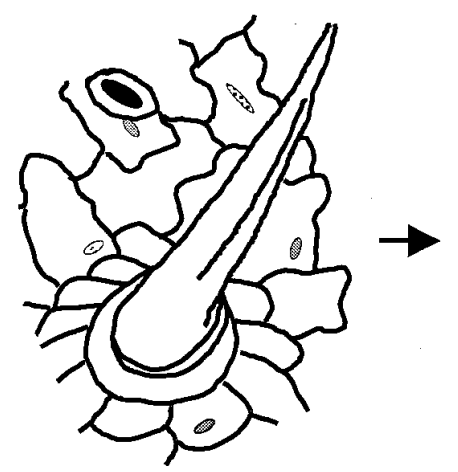

Step 1: Bacterial immigration

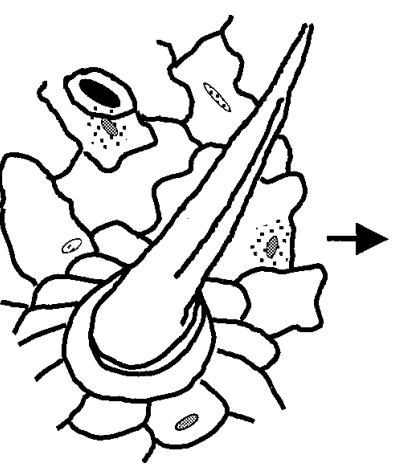

Step 2:

Habitat modification

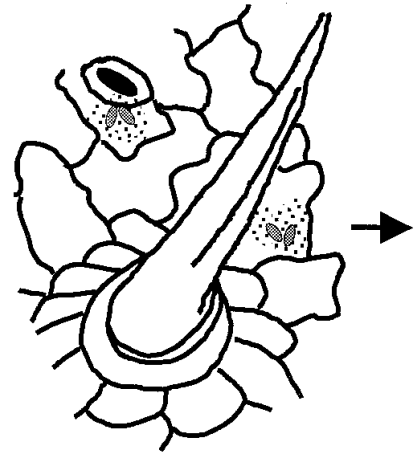

Step 3:

Bacterial division

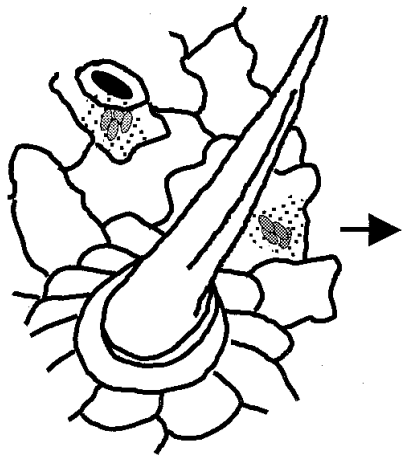

Step 4: Microcolony formation

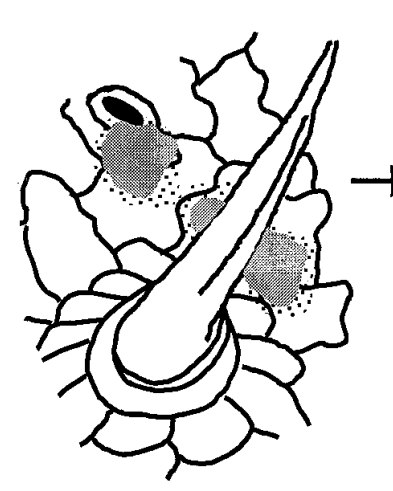

Step 5: Large aggregate formation

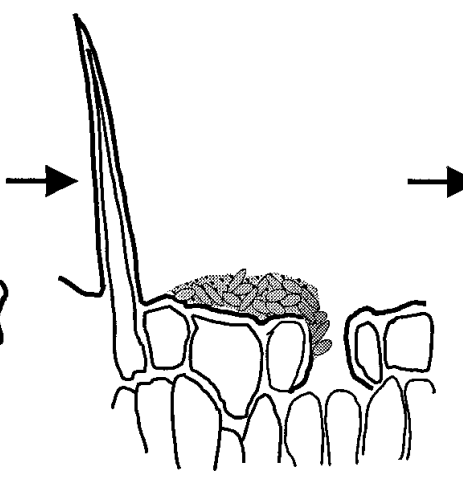

Step 6: Entry into internal spaces

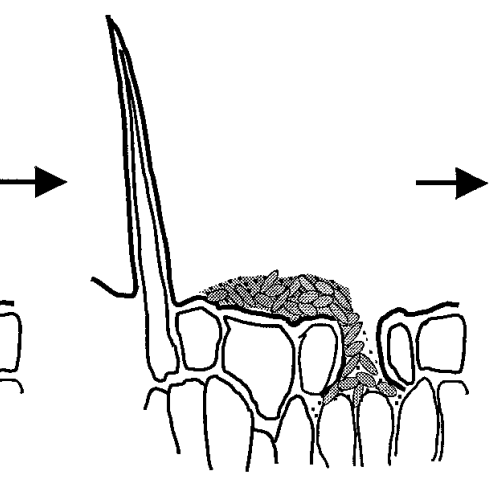

Step 7:

Habitat modification and bacterial division

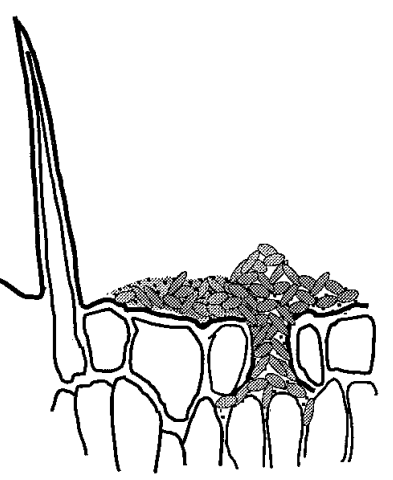

Step 8:

Egression onto the leaf surface

Fig. 1. Model of leaf colonization by phyllobacteria. 
located cells may result in phenotypes that promote internal colonization or vice versa. This phenomenon was suggested by the recent demonstration that $X$. campestris pv. campestris cells in early stationary phase entered leaf hydathodes in greater numbers than did exponential-phase cells (44).

With some foliar pathogens including $X$. campestris pv. vesicatoria on tomato and pepper and $X$. campestris pv. pruni on peach, external population sizes do not appear to be related to disease occurrence (M. Wilson, personal communication). This lack of a relationship may result from the process by which external and internal populations develop. For example, some organisms such as $P$. syringae pv. syringae may establish external populations immediately following inoculation, and these populations may increase the probability for ingress, thus increasing the probability for disease. Other organisms such as $X$. campestris pv. vesicatoria may not grow well on leaf surfaces following inoculation, but, following ingress of a few cells, may develop large internal populations that subsequently egress onto the leaf surface. In this case, the extent of egression that occurs prior to disease induction is likely to determine whether or not there is a relationship between external population size and disease occurrence.

\section{MODEL OF LEAF COLONIZATION BY PHYLLOBACTERIA}

Distinct phyllobacterial species probably colonize leaves in different ways. Due to the similarities among bacteria in their requirements for growth and survival, however, the colonization strategies of these distinct species must contain at least some common elements. Based on the concepts detailed above, we have derived a general model of leaf colonization that represents how many of these bacteria including foliar pathogens colonize leaves. This model is illustrated in Figure 1 and involves the following steps.

Step 1. Bacteria arrive on the leaf surface via airborne, waterborne, or vector deposition and are randomly distributed across the leaf surface, usually in the form of individual cells or small clumps of cells.

Step 2. While some of these cells may enter into the leaf via openings such as stomata or hydathodes, many of those on the surface modify their local environment. This may occur by mechanisms such as enhancing nutrient release from the plant leaf and producing extracellular polysaccharides.

Step 3. The bacteria that can modify their environment divide, and their increased cell numbers facilitate further habitat modification. Those surface bacteria that do not modify their environment have a lower probability of survival.

Step 4. Bacterial multiplication results in the formation of a microcolony. This microcolony may be either homogeneous, if it contains only progeny from a single cell, or heterogeneous, if other cells are incorporated into it. Heterogeneity may result from immigration subsequent to multiplication, envelopment of one or more neighboring cells into the microcolony, or convergence of microcolonies. If incorporation of a cell into a microcolony enhances its ability to multiply or survive, such incorporation would be an important process in community development.

Step 5. The microcolonies develop into large aggregates that, like the microcolonies themselves, may be either homogeneous or heterogeneous in bacterial composition.

Step 6. At least for foliar pathogens, the bacteria enter into the internal spaces of the leaves. High density growth in aggregates may facilitate ingress by density- or growth stage-dependent gene induction that results in phenotypes that aid in ingress.

Step 7. The bacteria multiply in the leaf intercellular spaces, aided by their ability to modify the intercellular habitat.

Step 8. The bacteria egress onto the leaf surface. This egression may be mediated or enhanced by water-soaking or canker or lesion formation.

In proposing this model, we envision that these steps vary in importance for distinct bacterial species. For example, some foliar pathogens, designated type I, may fall on one end of a spectrum and may develop large external populations following immigration or inoculation (steps 3 to 5). Others, designated type II, may fall on the opposite end of a spectrum and may develop only small external populations. Following entry into the leaves and multiplication within the intercellular spaces (steps 6 and 7), the egression that occurs (step 8) may contribute only a small amount to the epiphytic population size (type I pathogens) or may be the major contributor to the external populations (type II pathogens). Thus, for type I pathogens, large external populations may be predictive of disease occurrence, since they occur before the development of internal populations and disease induction. In contrast, for type II pathogens, large external populations may not be predictive of disease occurrence, since they may develop concomitant with or after the establishment of internal populations and disease induction. In this manner, application of this model to various phytopathogenic bacterial species may provide insight into the epidemiology of the species. Other applications of this model may increase our ability to predict the efficacy of potential biocontrol agents and improve our understanding of the autoecology of individual phyllobacterial species.

\section{ACKNOWLEDGMENTS}

Journal Paper No. J-18292 of the Iowa Agriculture and Home Economics Experiment Station, Ames, Project No. 3433. This work was supported, in part, by Hatch Act and State of Iowa funds, and by the Department of Energy grant DE-FG03-86ER13518. We thank M. Wilson and two anonymous reviewers for their helpful comments and critique of this mini-review.

\section{LITERATURE CITED}

1. Addy, S. K. 1976. Leakage of electrolytes and phenols from apple leaves caused by virulent and avirulent strains of Erwinia amylovora. Phytopathology 66:1403-1405.

2. Allington, W. B., and Chamberlain, D. W. 1949. Trends in the population of pathogenic bacteria within leaf tissues of susceptible and immune plant species. Phytopathology 39:656-660.

3. Atkinson, M. M., and Baker, C. J. 1987. Association of host plasma membrane $\mathrm{K}^{+} / \mathrm{H}^{+}$exchange with multiplication of Pseudomonas syringae pv. syringae in Phaseolus vulgaris. Phytopathology 77:1273-1279.

4. Atkinson, M. M., and Baker, C. J. 1987. Alteration of plasmalemma sucrose transport in Phaseolus vulgaris by Pseudomonas syringae pv. syringae and its association with $\mathrm{K}^{+} / \mathrm{H}^{+}$exchange. Phytopathology 77 : 1573-1578.

5. Barnes, E. S. 1965. Bacteria on leaf surfaces and in intercellular leaf spaces. Science 147:1151-1152.

6. Bashan, Y., Diab, S., and Okon, Y. 1982. Survival of Xanthomonas campestris pv. vesicatoria in pepper seeds and roots in symptomless and dry leaves in non-host plants in the soil. Plant Soil 68:161-170.

7. Bashan, Y., Sharon, E., Okon, Y., and Henis, Y. 1981. Scanning electron and light microscopy of infection and symptom development in tomato leaves infected with Pseudomonas tomato. Physiol. Plant Pathol. 19: 139-144.

8. Beattie, G. A., and Lindow, S. E. 1994. Survival, growth and localization of epiphytic fitness mutants of Pseudomonas syringae on leaves. Appl. Environ. Microbiol. 60:3790-3798.

9. Beattie, G. A., and Lindow, S. E. 1994. Comparison of the behavior of epiphytic fitness mutants of Pseudomonas syringae under controlled and field conditions. Appl. Environ. Microbiol. 60:3799-3808.

10. Beattie, G. A., and Lindow, S. E. 1995. The secret life of foliar bacterial pathogens on leaves. Annu. Rev. Phytopathol. 33:145-172.

11. Beck-VonBodman, S., and Farrand, S. K. 1995. Capsular polysaccharide biosynthesis and pathogenicity in Erwinia stewartii require induction by an N-acylhomoserine lactone autoinducer. J. Bacteriol. 177:5000-5008.

12. Bedford, K. E., MacNeill, B. H., Bonn, W. G., and Dirks, V. A. 1988. Population dynamics of Pseudomonas syringae pv. papulans on Mutsu apple. Can. J. Plant Pathol. 10:23-29.

13. Bender, C. L., Stone, H. E., Sims, J. J., and Cooksey, D. A. 1987. Reduced pathogen fitness of Pseudomonas syringae pv. tomato Tn5 mutants defective in coronatine production. Physiol. Mol. Plant Pathol. 30:273-283.

14. Blakeman, J. P. 1985. Ecological succession of leaf surface microorganisms in relation to biological control. Pages 6-30 in: Biological Control on the Phylloplane. C. E. Windels and S. E. Lindow, eds. The American Phytopathological Society, St. Paul, MN. 
15. Brandl, M. T., and Lindow, S. E. 1998. Contribution of indole-3-acetic acid production to the epiphytic fitness of Erwinia herbicola. Appl. Environ. Microbiol. 64:3256-3263.

16. Burkowicz, A., and Goodman, R. N. 1969. Permeability alterations induced in apple leaves by virulent and avirulent strains of Erwinia amylovora. Phytopathology 59:314-318.

17. Cafati, C. R., and Saettler, A. W. 1980. Effect of host on multiplication and distribution of bean common blight bacteria. Phytopathology 70: 675-679.

18. Corpe, W. A., and Rheem, S. 1989. Ecology of the methylotrophic bacteria on living leaf surfaces. FEMS (Fed. Eur. Microbiol. Soc.) Microbiol. Ecol. 62:243-250.

19. Costerton, J. W., Lewandowski, Z., Caldwell, D. E., Korber, D. R., and Lappin-Scott, H. M. 1995. Microbial biofilms. Annu. Rev. Microbiol. 49:711-745

20. Dane, F., and Shaw, J. J. 1996. Survival and persistence of bioluminescent Xanthomonas campestris pv. campestris on host and non-host plants in the field environment. J. Appl. Bacteriol. 80:73-80.

21. Daub, M. E., and Hagedorn, D. J. 1979. Resistance of Phaseolus line WBR 133 to Pseudomonas syringae. Phytopathology 69:946-951.

22. Davis, C. L., and Brlansky, R. H. 1991. Use of immunogold labelling with scanning electron microscopy to identify phytopathogenic bacteria on leaf surfaces. Appl. Environ. Microbiol. 57:3052-3055.

23. De Cleene, M. 1989. Scanning electron microscopy of the establishment of compatible and incompatible Xanthomonas campestris pathovars on the leaf surface of Italian ryegrass and maize. Bull. OEPP (Organ. Eur. Mediterr. Prot. Plant.)/EPPO (Eur. Mediterr. Plant Prot. Organ.) Bull. 19:81-88.

24. Denny, T. P. 1995. Bacterial polysaccharides as determinants of pathogenicity and virulence. Annu. Rev. Phytopathol. 33:173-197.

25. Dienelt, M. M., and Lawson, R. H. 1989. Histopathology of Xanthomonas campestris pv. citri from Florida and Mexico in wound-inoculated detached leaves of Citrus aurantifolia: Transmission electron microscopy. Phytopathology 79:336-348.

26. Duveiller, E., and Maraite, H. 1995. Effect of temperature and air humidity on multiplication of Xanthomonas campestris. pv. undulosa and symptom expression in susceptible and field-tolerant wheat genotypes. J. Phytopathol. 143:227-232.

27. Egel, D. S., Graham, J. H., and Riley, T. D. 1991. Population dynamics of strains of Xanthomonas campestris differing in aggressiveness on Swingle citrumelo and grapefruit. Phytopathology 81:666-671.

28. El-Banoby, F. E., and Rudolph, K. 1979. Induction of water-soaking in plant leaves by extracellular polysaccharides from phytopathogenic pseudomonads and xanthomonads. Physiol. Plant Pathol. 15:341-349.

29. Ercolani, G. L. 1973. Two hypotheses on the aetiology of response of plants to phytopathogenic bacteria. J. Gen. Microbiol. 74:83-95.

30. Fett, W. F., Osman, S. F., and Dunn, M. F. 1987. Auxin production by plant pathogenic pseudomonads and xanthomonads. Appl. Environ. Microbiol. 53:1839-1845.

31. Fry, S. C. 1989. Cellulases, hemicelluloses and auxin-stimulated growth: A possible relationship. Physiol. Plant. 75:532-536.

32. Glickmann, E., Gardan, L., Jacquet, S., Hussain, S., Elasri, M., Petit, A., and Dessaux, Y. 1998. Auxin production is a common feature of most pathovars of Pseudomonas syringae. Mol. Plant-Microbe Interact. 11: 156-162.

33. Goldberg, R. 1975. Cell wall polysaccharidase activities and growth processes: A possible relationship. Physiol. Plant. 50:261-264.

34. Greenberg, E. P. 1997. Quorum sensing in gram-negative bacteria. Am. Soc. Microbiol. News 63:371-377.

35. Gross, D. C. 1991. Molecular and genetic analysis of toxin production by pathovars of Pseudomonas syringae. Annu. Rev. Phytopathol. 29: 247-278.

36. Haefele, D. M., and Lindow, S. E. 1987. Flagellar motility confers epiphytic fitness advantages upon Pseudomonas syringae. Appl. Environ. Microbiol. 53:2528-2533.

37. Henis, Y., Okon, Y., Sharon, E., and Bashan, Y. 1980. Detection of small numbers of phytopathogenic bacteria using the host as an enrichment medium. J. Appl. Bacteriol. 49:vi.

38. Hirano, S. S., Ostertag, E. M., Savage, S. A., Baker, L. S., Willis, D. K., and Upper, C. D. 1997. Contribution of the regulatory gene lemA to field fitness of Pseudomonas syringae pv. syringae. Appl. Environ. Microbiol. 63:4304-4312.

39. Hirano, S. S., Rouse, D. I., Arny, D. C., Nordheim, E. V., and Upper, C. D. 1981. Epiphytic ice nucleation active (INA) bacterial populations in relation to halo blight incidence in oats. (Abstr.) Phytopathology 71:881.

40. Hirano, S. S., and Upper, C. D. 1983. Ecology and epidemiology of foliar bacterial plant pathogens. Annu. Rev. Phytopathol. 21:243-269.

41. Hirano, S. S., and Upper, C. D. 1990. Population biology and epidemiology of Pseudomonas syringae. Annu. Rev. Phytopathol. 28:155-177.

42. Hirano, S. S., and Upper, C. D. 1993. Dynamics, spread, and persis- tence of a single genotype of Pseudomonas syringae relative to those of its conspecifics on populations of snap bean leaflets. Appl. Environ. Microbiol. 59:1082-1091.

43. Huang, H.-C., Hutcheson, S. W., and Collmer, A. 1991. Characterization of the hrp cluster from Pseudomonas syringae pv. syringae 61 and TnphoA tagging of genes encoding exported or membrane-spanning Hrp proteins. Mol. Plant-Microbe Interact. 4:469-476

44. Hugouvieux, V., Barber, C. E., and Daniels, M. J. 1998. Entry of Xanthomonas campestris pv. campestris into hydathodes of Arabidopsis thaliana leaves: A system for studying early infection events in bacterial pathogenesis. Mol. Plant-Microbe Interact. 11:537-543.

45. Ji, P., Campbell, H. L., Lindow, S. E., and Wilson, M. 1996. Determination of the importance of nutritional similarity between biocontrol agents and the target pathogen in biocontrol of Pseudomonas syringae pv. tomato on tomato. (Abstr.) Phytopathology 86:S50.

46. Ji, P., Wilson, M., Campbell, H. L., and Lindow, S. E. 1997. Determination of the importance of pre-emptive carbon source use by nonpathogenic bacteria in the biocontrol of bacterial speck of tomato. (Abstr.) Phytopathology 87:S48.

47. Kamoun, S., and Kado, C. I. 1990. A plant-inducible gene of Xanthomonas campestris pv. campestris encodes an exocellular component required for growth in the host and hypersensitivity on nonhosts. J. Bacteriol. 172:5165-5172.

48. Kamoun, S., and Kado, C. I. 1990. Phenotypic switching affecting chemotaxis, xanthan production, and virulence in Xanthomonas campestris. Appl. Environ. Microbiol. 56:3855-3860.

49. Kingsley, M. T., Gabriel, D. W., Marlow, G. C., and Roberts, P. D. 1993. The opsX locus of Xanthomonas campestris affects host range and biosynthesis of lipopolysaccharide and extracellular polysaccharide. J. Bacteriol. 175:5839-5850.

50. Kinkel, L., Wilson, M., and Lindow, S. E. 1995. Effects of scale on estimates of epiphytic bacterial populations. Microbiol. Ecol. 29:283-297.

51. Kinkel, L. L., Wilson, M., and Lindow, S. E. 1996. Utility of microcosm studies for predicting phylloplane bacterium population sizes in the field. Appl. Environ. Microbiol. 62:3413-3423.

52. Leben, C. 1965. Epiphytic microorganisms in relation to plant disease. Annu. Rev. Phytopathol. 3:209-230.

53. Leben, C. 1969. Colonization of soybean buds by bacteria: Observations with the scanning electron microscope. Can. J. Microbiol. 15:319-320.

54. Leben, C. 1981. How plant-pathogenic bacteria survive. Plant Dis. 65: 633-637.

55. Leben, C. 1988. Relative humidity and the survival of epiphytic bacteria with buds and leaves of cucumber plants. Phytopathology 78:179-185.

56. Leben, C., Schroth, M. N., and Hildebrand, D. C. 1970. Colonization and movement of Pseudomonas syringae on healthy bean seedlings. Phytopathology 60:677-680.

57. Legard, D. E., McQuilken, M. P., Whipps, J. W., Fenlon, J. S., Fermor, T. R., Thompson, I. P., Bailey, M. J., and Lynch, J. M. 1994. Studies of seasonal changes in the microbial populations on the phyllosphere of spring wheat as a prelude to the release of a genetically modified microorganism. Agric. Ecosyst. Environ. 50:87-101.

58. Leopold, A. C., and Kriedemann, P. E. 1975. Plant Growth and Development. McGraw-Hill, New York.

59. Lindemann, J., Arny, D. C., and Upper, C. D. 1984. Epiphytic populations of Pseudomonas syringae pv. syringae on snap bean and nonhost plants and the incidence of bacterial brown spot disease in relation to cropping patterns. Phytopathology 74:1329-1333.

60. Lindow, S. E., Arny, D. C., Upper, C. D., and Barchet, W. R. 1978. The role of bacterial ice nuclei in frost injury to sensitive plants. Pages 249263 in: Plant Cold Hardiness and Freezing Stress: Mechanisms and Crop Implications. P. H. Li and A. Sakai, eds. Academic Press, New York.

61. Lindow, S. E., Desurmont, C., Elkins, R., McGourty, G., Clark, E., and Brandl, M. T. 1998. Occurrence of indole-3-acetic acid-producing bacteria on pear trees and their association with fruit russet. Phytopathology 88:1149-1157.

62. Mansvelt, E. L., and Hattingh, M. J. 1987. Scanning electron microscopy of colonization of pear leaves by Pseudomonas syringae pv. syringae. Can. J. Bot. 65:2517-2522.

63. Mansvelt, E. L., and Hattingh, M. J. 1989. Scanning electron microscopy of invasion of apple leaves and blossoms by Pseudomonas syringae pv. syringae. Appl. Environ. Microbiol. 55:533-538.

64. Manulis, S., Haviv-Chesner, A., Brandl, M. T., Lindow, S. E., and Barash, I. 1998. Differential involvement of indole-3-acetic acid biosynthetic pathways in pathogenicity and epiphytic fitness of Erwinia herbicola pv. gypsophilae. Mol. Plant-Microbe Interact. 11:634-642.

65. Mariano, R. L. R., and McCarter, S. M. 1993. Epiphytic survival of Pseudomonas viridiflava on tomato and selected weed species. Microbiol. Ecol. 26:47-58.

66. Mazzola, M., and White, F. F. 1994. A mutation in the indole-3-acetic 
acid biosynthetic pathway of Pseudomonas syringae pv. syringae affects growth in Phaseolus vulgaris and syringomycin production. J. Bacteriol. 176:1372-1382.

67. Mew, T. W., and Kennedy, B. W. 1982. Seasonal variation in populations of pathogenic pseudomonads on soybean leaves. Phytopathology 72:103-105.

68. Mew, T. W., Mew, I. C., and Huang, J. S. 1984. Scanning electron microscopy of virulent and avirulent strains of Xanthomonas campestris pv. oryzae on rice leaves. Phytopathology 74:635-641.

69. Mew, T. W., and Vera Cruz, C. M. 1986. Epiphytic colonization of host and non-host plants by phytopathogenic bacteria. Pages 269-282 in: Microbiology of the Phyllosphere. N. J. Fokkema and J. van den Heuvel, eds. Cambridge University Press, New York.

70. Miles, W. G., Daines, R. H., and Rue, J. W. 1977. Presymptomatic egress of Xanthomonas pruni from infected peach leaves. Phytopathology 67:895-897.

71. Morris, C. E., Monier, J.-M., and Jacques, M.-A. 1997. Methods for observing microbial biofilms directly on leaf surfaces and recovering them for isolation of culturable microorganisms. Appl. Environ. Microbiol. 63:1570-1576.

72. O'Brien, R. D., and Lindow, S. E. 1989. Effect of plant species and environmental conditions on epiphytic population sizes of Pseudomonas syringae and other bacteria. Phytopathology 79:619-627.

73. Patil, S. S., Hayward, A. C., and Emmons, R. 1974. An ultravioletinduced nontoxigenic mutant of Pseudomonas phaseolicola of altered pathogenicity. Phytopathology 64:590-595.

74. Pennycook, S. R., and Newhook, F. J. 1982. Ultraviolet sterilization in phylloplane studies. Trans. Br. Mycol. Soc. 78:360-361.

75. Pierson, L. S., Wood, D. W., Pierson, E. A., and Chancey, S. T. 1998. $\mathrm{N}$-acyl-homoserine lactone-mediated gene regulation in biological control by fluorescent pseudomonads: Current knowledge and future work. Eur. J. Plant Pathol. 104:1-9.

76. Roos, I. M. M., and Hattingh, M. J. 1983. Scanning electron microscopy of Pseudomonas syringae pv. morsprunorum on sweet cherry leaves. Phytopathol. Z. 180:18-25.

77. Roos, I. M. M., and Hattingh, M. J. 1987. Systemic invasion of plum leaves and shoots by Pseudomonas syringae pv. syringae introduced into petioles. Phytopathology 77:1253-1257.

78. Rouse, D. I., Nordheim, E. V., Hirano, S. S., and Upper, C. D. 1985. A model relating the probability of foliar disease incidence to the population frequencies of bacterial plant pathogens. Phytopathology 75:505-509.

79. Schneider, R. W., and Grogan, R. G. 1977. Tomato leaf trichomes, a habitat for resident populations of Pseudomonas tomato. Phytopathology 67:898-902.

80. Schultz, T., and Gabrielson, R. L. 1986. Xanthomonas campestris pv. campestris in western Washington crucifer seed fields: Occurrence and survival. Phytopathology 76:1306-1309.

81. Shekhawat, G. S., and Patel, P. N. 1978. Histology of barley plant and rice leaf infected with Xanthomonas translucens f. sp. hordei. Phytopathol. Z. 93:105-112.

82. Smitley, D. R., and McCarter, S. M. 1982. Spread of Pseudomonas syringae pv. tomato and role of epiphytic populations and environmental conditions in disease development. Plant Dis. 66:713-717.

83. Spurr, Jr., H. W. 1979. Ethanol treatment-A valuable technique for foliar biocontrol studies of plant disease. Phytopathology 69:773-776.

84. Stadt, S. J., and Saettler, A. W. 1981. Effect of host genotype on multiplication of Pseudomonas phaseolicola. Phytopathology 71:1307-1310.

85. Stromberg, K. D., Kinkel, L. L., and Leonard, K. J. 1999. Relationship between phyllosphere population sizes of Xanthomonas translucens pv. translucens and bacterial leaf streak severity on wheat seedlings. Phytopathology 89:131-135.
86. Surico, G. 1993. Scanning electron microscopy of olive and oleander leaves colonized by Pseudomonas syringae subsp. savastanoi. J. Phytopathol. 138:31-40.

87. Swarup, S., De Feyter, R., Brlansky, R. H., and Gabriel, D. W. 1991. A pathogenicity locus from Xanthomonas citri enables strains from several pathovars of $X$. campestris to elicit cankerlike lesions on citrus. Phytopathology 81:802-809.

88. Swift, S., Bainton, N. J., and Winson, M. K. 1994. Gram-negative bacterial communication by $\mathrm{N}$-acyl homoserine lactones: A universal language? Trends Microbiol. 2:193-198.

89. Sztejnberg, A., and Blakeman, J. P. 1973. Ultraviolet-induced changes in populations of epiphytic bacteria on beetroot leaves and their effect on germination of Botrytis cinerea spores. Physiol. Plant Pathol. 3:443-451.

90. Thompson, I. P., Bailey, M. J., Fenlon, J. S., Fermor, T. R., Lilley, A. K., Lynch, J. M., McCormack, P. J., McQuilken, M. P., Purdy, K. J., Rainey, P. B., and Whipps, J. M. 1993. Quantitative and qualitative seasonal changes in the microbial community from the phyllosphere of sugar beet (Beta vulgaris). Plant Soil 150:177-191.

91. Thomson, S. V., Schroth, M. N., Moller, W. J., and Reil, W. O. 1976. Efficacy of bactericides and saprophytic bacteria in reducing colonization and infection of pear flowers by Erwinia amylovora. Phytopathology 66:1457-1459.

92. Timmer, L. W., Marois, J. J., and Achor, D. 1987. Growth and survival of xanthomonads under conditions nonconducive to disease development. Phytopathology 77:1341-1345.

93. Turner, J. G., and Taha, R. R. 1984. Contribution of tabtoxin to the pathogenicity of Pseudomonas syringae pv. tabaci. Physiol. Plant Pathol. 25:55-69.

94. Weller, D. M., and Saettler, A. W. 1980. Colonization and distribution of Xanthomonas phaseoli and Xanthomonas phaseoli var. fuscans in field-grown navy beans. Phytopathology 70:500-506.

95. Wheeler, H., and Hanchey, P. 1968. Permeability phenomena in plant disease. Annu. Rev. Phytopathol. 6:331-350.

96. Wilson, H. A., Lilly, V. G., and Leach, J. G. 1965. Bacterial polysaccharides. IV. Longevity of Xanthomonas phaseoli and Serratia marcescens in bacterial exudates. Phytopathology 55:1135-1138.

97. Wilson, M., Hirano, S. S., and Lindow, S. E. Location and survival of leaf-associated bacteria in relation to their potential for growth within the leaf. Appl. Environ. Microbiol. In press.

98. Wilson, M., and Lindow, S. E. 1994. Inoculum density-dependent mortality and colonization of the phyllosphere by Pseudomonas syringae. Appl. Environ. Microbiol. 60:2232-2237.

99. Wilson, M., and Lindow, S. E. 1994. Ecological differentiation and coexistence between epiphytic Ice ${ }^{+}$Pseudomonas syringae strains and an Ice- biological control agent. Appl. Environ. Microbiol. 60:3128-3137.

100. Wilson, M., and Lindow, S. E. 1994. Coexistence among epiphytic bacterial populations mediated through nutritional resource partitioning. Appl. Environ. Microbiol. 60:4468-4477.

101. Xu, G. W., and Gross, D. C. 1988. Evaluation of the role of syringomycin in plant pathogenesis by using Tn5 mutants of Pseudomonas syringae pv. syringae defective in syringomycin production. Appl. Environ. Microbiol. 54:1345-1353.

102. Yang, Y., De Feyter, R., and Gabriel, D. W. 1994. Host-specific symptoms and increased release of Xanthomonas citri and X. campestris $\mathrm{pv}$. malvacearum from leaves are determined by the 102-bp tandem repeats of $p t h A$ and $a v r b 6$, respectively. Mol. Plant-Microbe Interact. 7:345-355.

103. Yang, Y., Yuan, Q., and Gabriel, D. W. 1996. Watersoaking function(s) of XcmH1005 are redundantly encoded by members of the Xanthomonas avr/pth gene family. Mol. Plant-Microbe Interact. 9:105-113.

104. Young, J. M. 1974. Development of bacterial populations in vivo in relation to plant pathogenicity. N.Z. J. Agric. Res. 17:105-113. 